\title{
The Influence of Online Media on Muslim Radicalism Among Senior High School Students
}

\author{
DOI: https://doi.org/10.18196/afkaruna.v17i1.10747
}

\section{IQBAL MIFTAKHUL MUJTAHID', RIAN VEBRIANTO², MUSA THAHIR ${ }^{3}$, NELL YUSRO ${ }^{4}$}

Faculty of Law, Social and Political Sciences, Universitas Terbuka'

Faculty of Tarbiyah and Teacher Training, Universitas Islam Negeri Sultan Syarif Kasim Riau 2,3,4 Correspondence E-mail: rian.vebrianto@uin-suska.ac.id²

\begin{abstract}
The analysis of radicalism attitudes among students is triggered by the lack of supervision of information and communication technology usage. This study aims to find the attitude of radicalism among senior high school students based on gender. The research is designed with a quantitative approach. The data were collected using a questionnaire. This study involved 229 students selected by random sampling, with a total of 107 male and 122 female students. The data were collected using a questionnaire and essay. The data were further analysed qualitatively and quantitatively. The results of this study showed that in Part A, 34\% male and 19\% female students often sent and shared religious content and conflicts on social media. In Part B, 13\% male and 14\% female students agreed on courtship, marriages with different religion, polygamy, and divorce. In Part C, 2\% male and female students are anti-ideological and uphold Islamic law. Furthermore, in Part D, 67\% male and 46\% female students declare non-Muslims as infidel, and war is a part of jihad. Keywords: Radicalism; Senior High School (SMA, SMK and MAN), Gender
\end{abstract}

\footnotetext{
ABSTRAK

Analisis sikap radikalisme di kalangan mahasiswa dipicu oleh kurangnya pengawasan penggunaan teknologi informasi dan komunikasi. Oleh karena itu penelitian ini bertujuan untuk mengetahui sikap radikalisme di kalangan siswa SMA berbasis gender. Penelitian ini merupakan jenis penelitian survey (tinjauan) dengan pendekatan kuantitatif melibatkan 229 siswa yang dipilih secara random sampling, dengan jumlah 107 laki-laki dan 122 siswa perempuan. Pengumpulan data dilakukan dengan menggunakan kuesioner dan essay. Data tersebut selanjutnya dianalisis secara
} 
kualitatif dan kuantitatif. Hasil penelitian ini menunjukkan bahwa di Part A, 34\% laki-laki dan 19\% mahasiswi sering mengirim dan membagikan konten dan konflik agama di media sosial. Di Bagian B, 13\% siswa laki-laki dan 14\% perempuan setuju tentang pacaran, perkawinan beda agama, poligami, dan perceraian. Di Bagian C, $2 \%$ siswa laki-laki dan perempuan anti ideologis dan menjunjung tinggi hukum Islam. Lebih lanjut, di Bagian D, 67\% pria dan 46\% wanita menyatakan nonMuslim sebagai kafir, dan perang adalah bagian dari jihad.

Keywords: Radikalisme; Sekolah Menengah Atas (SMA, SMK dan MAN), Gender

\section{INTRODUCTION}

Personality, mindset, and knowledge of students are influenced by several factors constituting internal and external factors. Students are a component of the education system. Human resources were abundant in quality and quantity that are molded into persons exhibiting value, morals, and manner in seeking knowledge, which is the ultimate goal of National Education. This component is currently facing the threat of different ideologies that pose the risks of corrupting morals and personalities. Coupled with the feudalism system, it is feared that the seeds of radicalism have been planted that may sprout at any time in the future.

Radicalism is prone to be exhibited by teenagers, especially students. It may be attributable to the lack of understanding about tolerance behaviors and the importance of avoiding reproach behaviors, including hate speech on ethnicity, race, religion, and groups. Fadjar mentioned that research conducted by Institute for Islamic Studies and Peace (LaKIP) in 2010 showed that $48.9 \%$ of students in Jakarta, Bogor, Depok, Tangerang, and Bekasi approved of behaviors of Islamic Radicalism. ${ }^{1}$ There are several factors to radical behaviors, namely a) Frustration-Aggression Hypothesis (perceived deprivation, problems related to political, economic, and personal needs), b) Negative Identity Hypothesis (anger and helplessness involving a rejection of expected roles in family and society), c) Narcissistic Rage Hypothesis (mental issues, sociopathic, arrogant, narcissistic, personality disorder). ${ }^{2}$ Elaborated on the escalation of person's radical behaviors to terrorism which is affected by a number of factors, among them are differences in beliefs, ethnicity, socio economic status. ${ }^{3}$ The education world is unavoidably mentioned in the discussion of radical behaviors among students, such as in a study by, suggesting that radicalism has been a prominent issue in an educational institution. ${ }^{4}$ One example is a controversy in 2015 surrounding the findings of radical teachings contained in a student worksheet and Religious Education textbooks in 
Jombang, East Java, and Bandung, West Java. Social Media is a means of online social interaction where users can communicate and interact, exchange messages with each other, share and build networks (networking). ${ }^{5}$ Social media is an application that allows the creation and exchange of user-generated content. ${ }^{6}$

Other findings, one of them from the Ministry of Communication and Information Technology, shows that the role of parents is significant in controlling children's internet use. However, it turns out there are still many parents who are lagging in terms of mastery and use of digital media compared to their children. A shocking number of parents do not bother to monitor and oversee their children's internet and social media use. The positive and negative impacts of social media on children's moral education, taking VIII graders of SMP Negeri 2 Banda Aceh as the sample. ${ }^{7}$ The result showed that the negative impacts outweigh the positive ones. Early detection or recognition of student radical behaviors is vital, though gender-based studies are needed to develop training, education, and understanding program. Umar in pointed out that "gender" derives from a word in the English language, which means "sex." In Webster's New World Dictionary, gender is defined as distinguishable characteristics between men and women in terms of values and behaviors. 8

Internet stands for internetworking. In the Technical Career Survival Handbook, networking can be done using social media such as Facebook. Social media is increasingly being used as a platform for marketing and advertising activities. Organizations have spent a lot of time, money and resources on social media advertising. ${ }^{9}$ In the book A New Vision for Supporting Caregivers in the Future, the term media refers to a communication tool by which information can be disseminated to the general public (for example via radio, newspaper, or television). Although valuable knowledge can be circulated and gained from these resources, traditional media provide only one-way mechanisms for sharing information. On the other hand, social media makes it possible to share information and ideas collaboratively and to share in promoting connection, conversation, and community building by providing the opportunity to see what others are saying and to provide feedback. ${ }^{10}$ The nascent social media has participated in the historical process of social reform and change. ${ }^{11}$ According to research by Mitchell Hamilyon, Velitchka D. Kaltcheva, and Andrew J. Rohm, in their research they identified a social media strategy for brands related to interaction and immersion satisfaction 
based on the three types of customer values studied.

The reported findings offer important managerial and theoretical implications with regard to the effects of discrete social media interactions on customer value creation. ${ }^{12}$ Research by Farzana Parveen Tajudeen, Noor Ismawati Jaafar, and Sulaiman Ainin investigated the antecedents and impacts of social media use in organizations. This research uses technology, organizational, and environmental frameworks and includes certain introductory factors that are specific to the use of social media in organizations. Items for measuring different purposes of social media use in organizations were developed, which contributed to the increase in the measurement of social media use. This study develops and tests an integrated model that contributes to scientific research on social media and information systems. This study also helps organizations to understand the benefits of using social media and provides justification for investment in social media by organizations. ${ }^{13}$ On the other hand, social media has developed rapidly and has become a normal channel and a powerful tool for citizens to communicate and carry influential messages among the community.

Based on the description above, this study aims to examine radicalism behaviors among high school students exposed to social media which is broken down into several parts, namely Part A discussing the Use of Information and Communication Technology, Part B discussing Moral Behavior Based on Religious Belief, Part C discussing Islam and Nation Ideology and Part D discussing Islam and Personality.

\section{RESEARCH METHOD}

The design of a research is survey research design with a quantitative approach. ${ }^{14}$ The data were collected using a questionnaire. This questionnaire contains the use of social media in adolescents and exposure to radicalism which consists of Part A constituted the assessment to identify the percentage of male and female students using technology and information, Part $B$ constituted the assessment to identify student responses on behaviors, based on beliefs and morals, Part C constituted the assessment to identify student responses on Islamic Sharia and National Ideology, and Part D constituted the assessment in the form essay to identify student responses on Islam, State, and Radical Behaviors. This questionnaire was adapted from research and has received validation from 3 experts. ${ }^{15}$ This instrument is considered feasible to be carried out in research. 
This study was conducted to identify radicalism behaviors among high school students, including Public Senior High School (SMAN), Madrasah Aliyah Negeri (MAN), and Vocational High School (SMK) in Riau Province. Sampling was performed using a random sampling technique. The samples analyzed consisted of 65 students each from SMA and MA and 99 SMK students, totaling 229 students. This study involved 229 students selected by random sampling, with a total of 107 male and 122 female students. A Likert-scale questionnaire and essay were used for data collection, and the data were analyzed using SPSS For Window to descriptive analysis.

\section{DISCUSSION}

Before getting into the discussion, it will be explained the discussion for each section according to the theme in this instrument.

\section{The Use of Information and Communication Technology}

Items in Part A included A1 (the Role of Religion in Life), A2 (Islamic Boarding School [Pondok Pesantren]), A3 (Free Time Habits), A4 (Time of Internet Use), A5 (Devices for Accessing the Internet and Social Media), A6 (Device Ownership), A7 (Availability of Credit or Internet Connection), A8 (Purposes of Accessing Internet), A9 (Contents of Social Media and Internet Accessed), A10 (Use of Internet for Religious Sites), A1 1 (Administration or Membership in Social Media), A12 (Religious Information), A13 (Sharing of Religious Information), A14 (Reading Religious Information) and A15 (Religious Problems), which were presented in Figure 1 below.

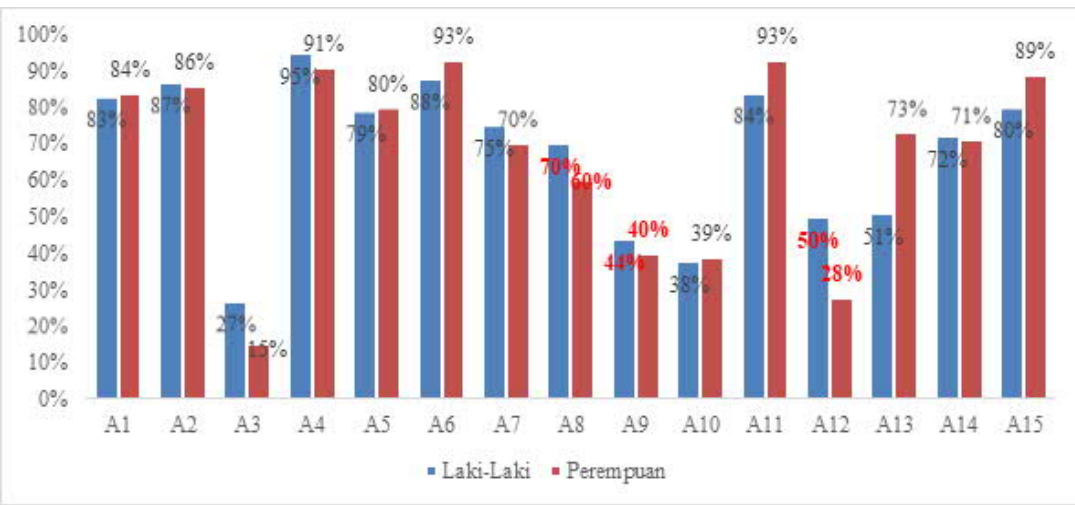

Figure 1. Student Responses on the Use of Information Technology and Islamic Information 
As seen in Figure 1, Part A constituted the assessment to identify the percentage of male and female students using technology and information. In A1, $83 \%$ of male students and $84 \%$ of female students stated that the role of religion was crucial in life. In A2, $87 \%$ of male students and $86 \%$ of female students stated that they never went to an Islamic boarding school. In A3, $27 \%$ of male students and $15 \%$ of female students stated that they frequently surfed the internet in their free time. In A4, 95\% of male students and $91 \%$ of female students stated that they spent more than 13 hours of their time to access the internet and social media. In A5, 79\% of male students and $80 \%$ of female students stated that they accessed social media through a smartphone. In A6, 88\% of male students and 93\% of female students stated that they owned their device to access the internet. In A7, 75\% of male students and $70 \%$ of female students stated that they bought a data plan on their own. In A8, 70\% of male students stated that they used the internet for playing online games, and $60 \%$ of female students stated that they used the internet for chatting or messaging.

Furthermore, in A9, 44\% of male students stated that they accessed social media and the internet for online games, and $40 \%$ of female students chose social interactions. In A10,38\% of male students and 39\% of female students stated that they elicited religious information from YouTube. In A11, $84 \%$ of male students and $93 \%$ of female students stated that their most used social media was WhatsApp. In A12, 50\% of male students stated that they preferred religious information regarding Islam History, while $28 \%$ of female students preferred Fiqh. In A13, 54\% of male students and $73 \%$ of male students preferred not to send or share religious information to other groups. In A14, $72 \%$ of male students and $71 \%$ of female students stated that they read religious information until the end. Lastly, in A15,80\% of male students and $89 \%$ of female students claimed that they never got involved in a religious conflict on social media.

Part B constituted the assessment to identify student responses on behaviors, based on beliefs and morals, such as (1) not covering intimate parts, (2) dating, (3) drugs and alcohol, (4) terrorism, (5) hate speech, (6) LGBT (Lesbian, Gay, Bisexual, and Transgender), (7) free sex and prostitution, (8) interfaith marriage, (9) polygamy, (10) divorce, (11) violence and (12) hoaxes, which were presented in Figure 2 below. 


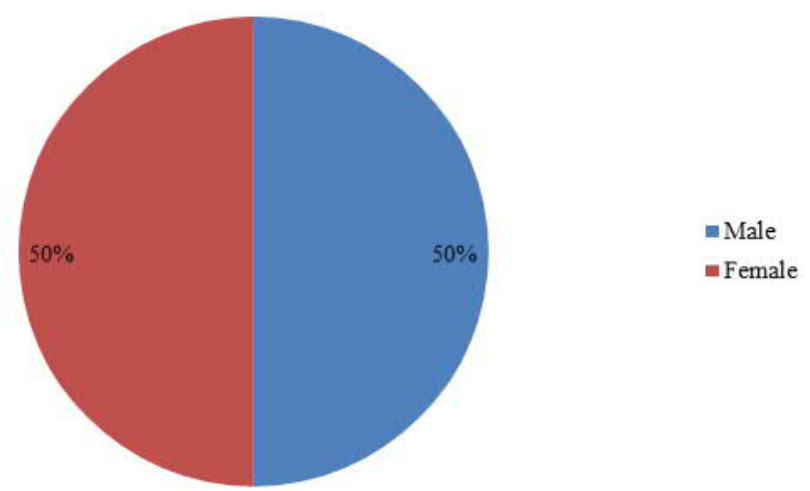

Figure 2. Male and Female Student Responses

Figure 2 showed that $50 \%$ of both male and female students had similar responses to deviant behaviors. Both student groups believed that religion is essential in life.

Part C constituted the assessment to identify student responses on Islamic Sharia and National Ideology, which included (1) Islam and Pancasila, (2) constitution, state form, and political and legal system, (3) Islam and nationalism, (4) Islam and diversity and (5) citizenship. Each item consisted of 5 parts, and the students indicated their preference using scales namely "Strongly Agree (SS)," "Agree (S)," "Undecided (R)," "Disagree (TS)," "Strongly Disagree (STS," which were presented in Figure 3 below.

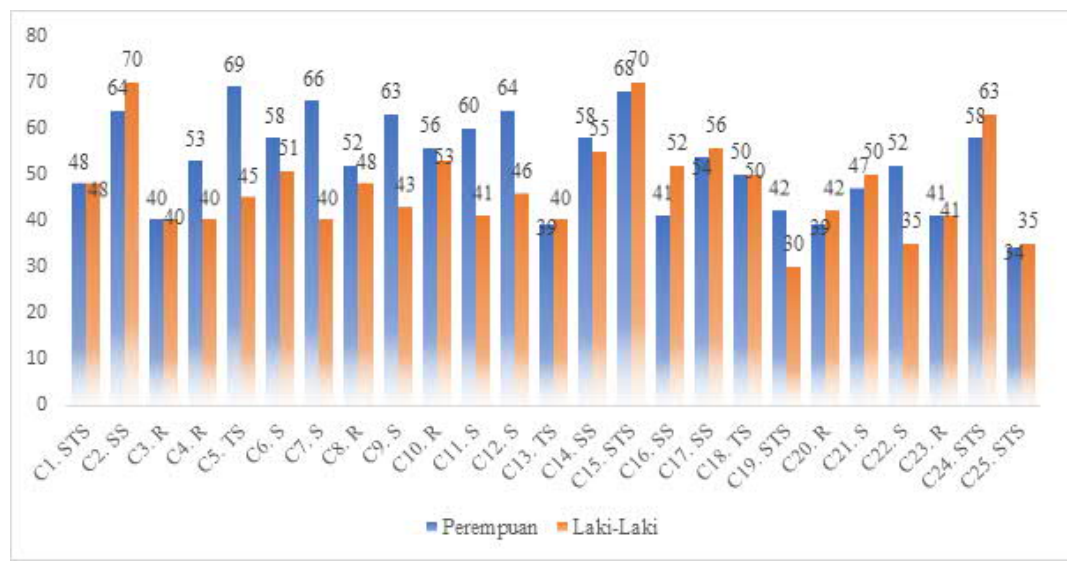

Figure 3. Responses on Religion and National Ideology 
Figure 3 showed part C1 to C5 regarding Islam and Pancasila. In Figure 4.17, for C1, 48 students, both male and female, "Strongly Disagreed (STS)" that Pancasila could be replaced by other ideology as the foundational philosophical theory of Indonesia. For C2, 64 male students and 70 female students "Strongly Agreed (SS)" that every Muslim must defend Pancasila as the foundation of the state. For C3, 40 students, both male, and female were "Undecided (R)," whether Pancasila could be replaced with Islam. For C4, 53 male students and 40 female students were "Undecided (R)," whether they were willing to get involved in the effort to replace Pancasila with Islam. Lastly, for C5, 69 male students and 45 female students "Strongly Disagreed (TS)" that Pancasila was no longer compatible with Islamic values.

Part C6 to C10 contained constitution, state form, and political and legal system. In Figure 4.17, for C6, 58 male students and 51 female students "Agreed (S)" that groups and followers of other religions must be protected. For C7, 66 male students and 40 female students "Agreed (S) that the 1945 Constitution was in line with Islamic teachings. For C8, 52 male students and 48 female students were "Undecided (R)," whether the state law applied in Indonesia was not kafir law. For C9, 63 male students and 43 female students "Agreed (S)" that the ideal state form for Indonesia was an Islamic state. For C10, 56 male students and 53 female students were "Undecided (R)" whether Islamic sharia should be implemented comprehensively (kaffah) without phasing throughout Indonesia.

Part C11 to C15 contained Islam and nationalism. In Figure 4.17, for C11, 60 male students, and 41 female students, "Agreed (S)" that NKR/ was the state form of Indonesia. For C12, 64 male students and 46 female students "Agreed (S)" that nationalism was Part or Islamic teachings. For C13, 39 male students and 40 female students "Disagreed (TS)" that patriotism was not Part of jihad. For C14, 58 male students and 55 female students "Strongly Agreed (SS)" that brotherhood was not only bound by religion but also nation. Lastly, for C15, 70 male students and 68 female students "Strongly Disagreed (STS)" that they refused to respect the flag during the ceremony.

Part C16 to C120 contained Islam and Diversity. In Figure 4.17, for C16, 41 male students and 52 female students "Strongly Agreed (SS)" that religion forbade imposing one's religion on others. In C17, 54 male students and 56 female students "Strongly Agreed (SS)" that religion did not forbid kindness toward all followers of all religions. In C18, 50 students, both male and female, "Disagreed (TS)" to avoid being friends with people from other faiths. 
In C19, 42 male students and 30 female students "Strongly Disagreed (STS)" that the best leader should be elected even if they are different in religion. In C20, 39 male students and 42 female students were "Undecided (R), " whether it is haram to have women as a leader.

Part C21 to C25 contained Citizenship. In Figure 4.17, for C21, 47 male students and 50 female students "Agreed (S)" to respect legitimate government. For C22, 52 male students and 35 female students "Agreed (S)" to respect the leader of other countries for the pursuance of "Khilafah Islamiyah." In C23, 41 students, both male and female, were "Undecided (R)" whether taking Part in the election was against the teachings of their religion. For C24, 58 male students and 63 female students "Strongly Disagreed (STS)" with the statement that bombing is divine command or jihad. Lastly, in C25, 34 male students and 35 female students "Strongly Disagreed (STS)" with the statement that jihad only meant war.

Activities of accompaniment, advocacy and raising awareness toward radicalism such as a) Reasoning, by strengthening the principle of Ahlissunnnah waljamaah an-Nahdliyyah; b) Administrative, by providing structured and systematic instructions from the center to the regions; c) Movement, by conducting training, institutional programs, and regeneration; and d) Situation response, by giving attitude statement, comments, criticism, and suggestion. ${ }^{16}$ The education world can also contribute by changing the learning system and curriculum. In order to prevent radicalism among students, the Indonesian Islamic Reasoning Program (PPII) is implemented by using collaborative learning from various approaches and methods in the process, such as meaningful learning, contextual teaching and learning, cooperative learning, active learning, and others. ${ }^{17}$ Besides, invited Islamic religious education teachers to conduct promotion related to the dangers of radicalism, empower mosques or school prayer rooms as centers of Islamic activities, protect student organizations such as Rohis (Rohani Islam) because radicalism often targets active children in schools, develop tolerance and instill plural life. ${ }^{18}$

Part D constituted the assessment in the form essay to identify student responses on Islam, State, and Radical Behaviors. It consisted of several matters, namely D1: "What and who is called kafir?", D2: "Non-Muslims equal kafir," D3: "What and who are considered radical?", D4: "Examples of Radicalism," D5: "What is meant by Islamic State?", D6: "Views on the Islamic State," D7: "Understanding of Islam Kaffah," D8: "Views on Jihad," D9: 


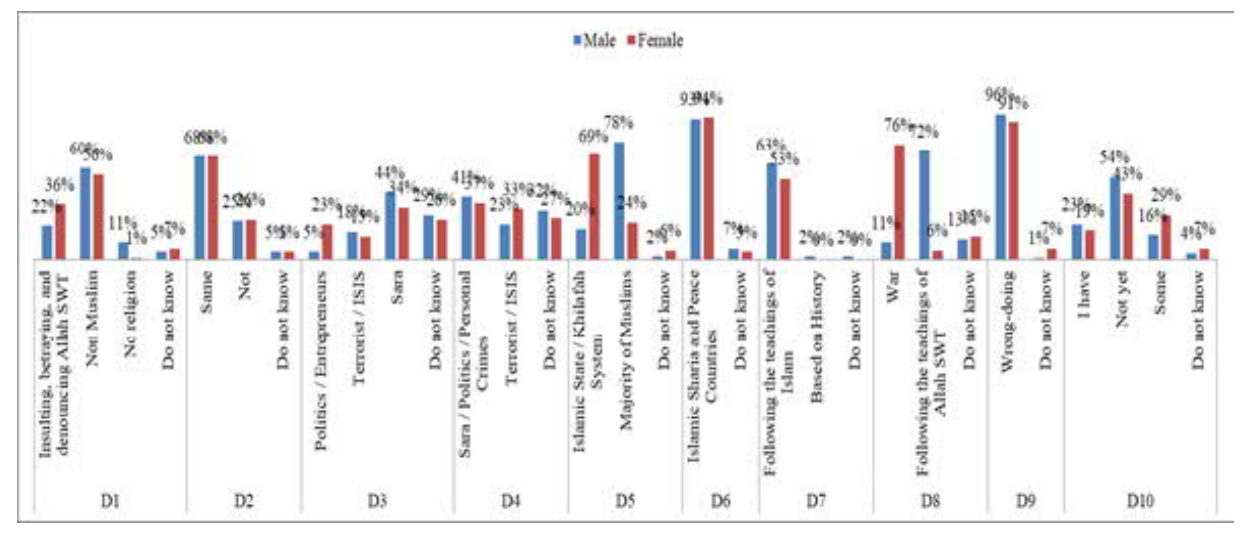

Figure 4. Responses on Islam, State, and Radicalism

"Views on Suicide Bombing in Indonesia," and D10: "Has Indonesia Implemented Islamic Sharia Law?". These were presented in Figure 4.

Figure 4 showed that on D1, 56\% of male students and $60 \%$ of female students answered that kafir people are "Non-Muslims." On D2, 68\% of students, both male and female, answered that "Non-Muslims equal kafir." On D3, 34\% of male students and 44\% of female students answered that "Insulting Ethnicity, Religion, Race and Intergroup Relation is Radicalism." On D4, 37\% of male students and $41 \%$ of female students stated the instance of radicalism was "Harassment Based on Ethnicity, Religion, Race and Intergroup Relations." On D5, 78\% of female students replied that an Islamic State was "A Muslim-Majority Country," while $69 \%$ of male students answered "Islamic Country or Caliphate System."

On D6, 94\% of male students and 93\% of female students responded based on their perspectives that an Islamic State was "A Country That Practices Islamic Sharia and Are Peaceful, Just and Prosperous." On D7, 53\% of male students and $63 \%$ of female students believed that Islam Kaffah meant "Practicing Islamic Teachings Comprehensively." On D8, 76\% of male students believed that jihad was "War," while $72 \%$ of female students believed that jihad meant "Following All Teachings and Commandments." On D9, $91 \%$ of male students and $96 \%$ of female students expressed that suicide bombing was "A Wrong and Despicable Action." Lastly, on D10, 43\% of male students and $54 \%$ of female students perceived that Islamic Sharia Law in Indonesia "Has Not Been Implemented."

Based on the responses on parts $A, B, C$, and D, the total results were summarized in the following figure. 


\section{Personality Assessment}

- Male $n$ Female

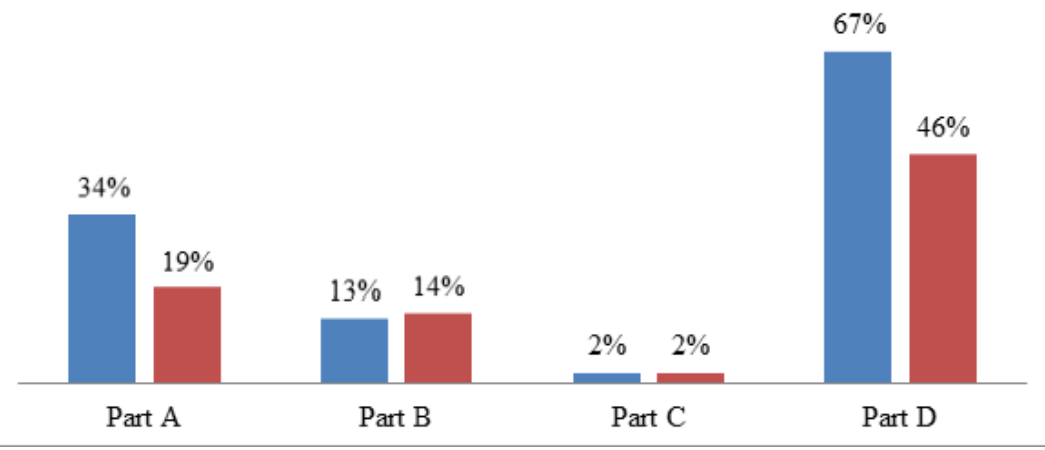

Figure 5. Responses on Islam, State, and Radicalism

Based on Figure 5, in Part A, 34\% of male students and $19 \%$ of female students frequently sent and shared religious contents and religious conflicts on social media. In Part B, $13 \%$ of male students and $14 \%$ of female students condone Dating, Interfaith Marriage, Polygamy, and Divorce. In Part C, 2\% of students, both male, and female, were anti-ideology and upheld Islamic sharia. In Part D, $67 \%$ of male students and $46 \%$ of female students stated that Non-Muslims were kafir, and the war was considered jihad (misconception of real jihad).

Moreover, Part D shows that the seeds of radicalism may sprout in the absence of proper teaching and understanding to suppress the behaviors. Pointed out that ancient human history presents more than enough evidence that a nation could collapse when moral degradation goes out of control, people start to stray away from religious teachings and disobey laws. ${ }^{19}$ When students have graduated from high school or equivalent, organizational tendencies in higher education such as college or Gesellschaft may develop. NU Conference in 2015 mapped the characteristics of some potentially radical cohorts such as Takfiri, Jihadi, Siyasi and Salafi movements. ${ }^{20}$

The fundamentalist view poses a significant danger to life, especially women. Fundamentalism rejects the principle of justice and gender equality, birth control, sexual education, reproduction health, people with HIV or AIDS, and condemns rape victim and sex worker union. ${ }^{21}$ For Part B, $6 \%$ of respondents stated that deviant or immoral behaviors and religiousness are the benchmarks in fundamentalism. According to Aminah ${ }^{22}$, deradicalization or trans- 
formation is needed to ward off radicalism, and it can be realized by 1) changing egoistic behavior toward the truth of other people or groups into a more open, pluralistic behavior; 2) transforming the concept of a symbolic identity into a concept that is understood substantially and has universal value; 3 ) transforming the closed textual corpus understanding into a more open contextual corpus.

Described activities of accompaniment, advocacy and raising awareness toward radicalism such as a) Reasoning, by strengthening the principle of Ahlissunnnah waljamaah an-Nahdliyyah; b) Administrative, by providing structured and systematic instructions from the center to the regions; c) Movement, by conducting training, institutional programs, and regeneration; and d) Situation response, by giving attitude statement, comments, criticism, and suggestion. The education world can also contribute by changing the learning system and curriculum..$^{23}$ In order to prevent radicalism among students, the Indonesian Islamic Reasoning Program (PPII) is implemented by using collaborative learning from various approaches and methods in the process, such as meaningful learning, contextual teaching and learning, cooperative learning, active learning, and others. ${ }^{24}$ Besides, Islamic religious education teachers to conduct promotion related to the dangers of radicalism, empower mosques or school prayer rooms as centers of Islamic activities, protect student organizations such as Rohis (Rohani Islam) because radicalism often targets active children in schools, develop tolerance and instill plural life. ${ }^{25}$ Last but not least important, the family also plays an essential role in combating radical behaviors. Radicalism can be driven away through the synergy between father and mother. ${ }^{26}$ Educating children is not only the responsibility of one parent but a shared responsibility. A harmonious relationship between the two becomes the main instrument in warding off radicalism.

\section{CONCLUSION}

Based on the results of the study, it can be concluded that: 1) without proper supervision, social media can harm students. It is evidenced by the discovery of religious conflict, differences in perception, and social by $17.5 \%$; and 2 ) in Part A, 34\% of male students and 19\% of female students regularly send and share religious contents and religious conflicts on social media. In Part B, $13 \%$ of male students and $14 \%$ of female students condone dating, interfaith marriage, polygamy, and divorce. In Part C, $2 \%$ of male students 
and female students are anti-ideology and uphold Islamic sharia. In Part D, $67 \%$ of male students and $46 \%$ of female students expressed that non-Muslims are kafir, and war is considered jihad (misconception of real jihad).

From this research, it can be seen that social media can be a way to provoke both men and women to commit radicalism if they have a narrow understanding of religion and of course the role of the family is the most important main fortress in dealing with this understanding of radicalism from various sources, both social media and recitation which is realized by the family. This also implies for the government to always provide an understanding of religious moderation in various ways and information that is right on target.

\section{ACKNOWLEDGMENT}

This research was conducted with the cooperation and support of student Open University and UIN Sultan Syarif Kasim Riau in helping to make this research successful and effective.

\section{ENDNOTES}

1 Ahmad Sholikin, "Potret Sikap Radikalisme Menuju Pada Perilaku Terorisme Di Kabupaten Lamongan”, Journal of Governance, Vol. 3 No. 2 (2018), p. 184202,.

2 Kuntarto Kuntarto and Rindha Widyaningsih, "Prosiding Seminar Nasional Dan Call for Papers", in Prosiding Seminar Nasional dan Call for Papers, "Pengembangan Sumber Daya Perdesaan dan Kearifan Lokal Berkelanjutan VIII", (Purwokerto, 2018), p. 218-226,.

3 Ahmad Sholikin, Loc.Cit.

4 Jakaria Umro, "Upaya Guru Pendidikan Agama Islam Dalam Mencegah Radikalisme Agama Di Sekolah”, Journal Of Islamic Education (JIE), Vol. 2 No. 1 (2017), p. 89-108,.

5 Andang Sunarto, "Dampak Media Sosial Terhadap Paham Radikalisme", Nuansa, Vol. 10 No. 2 (2017), p. 126-132,.

6 Andreas M Kaplan and Michael Haenlein, "Users of the World, Unite/! The Challenges and Opportunities of Social Media”, Business Horizons, Vol. 53 (2010), p. 59-68, https://doi.org/10.1016/j.bushor.2009.09.003.

7 Nisa Khairuni, "Dampak Positif dan Negatif Sosial Media Terhadap Pendidikan Akhlak Anak.”, Jurnal Edukasi, Vol. 2 No. 1 (2016), p. 91-106,.

8 Titis Rosowulan, "Gerakan Kesetaraan Gender antara Modetarisme Islam dan Radikal”, Wahana Islamika: Jumal Studi Keislaman, Vol. 3 No. 1 (2017), p. 22 42 .

9 A. A. Alalwan, "Investigating the Impact of Social Media Advertising Features 
on Customer Purchase Intention”, International Journal of Information Management, Vol. 42 (2018), p. 65-77, https://doi.org/https://doi.org/10.1016/ j.ijinfomgt.2018.06.001.

10 K Nikzad-Terhune et al., "The Impact of the Internet and Social Media on Caregiving”, Family Caregiving in the New Normal, 2015, p. 269-289, https:// doi.org/https://doi.org/10.1016/B978-0-12-417046-9.00015-5.

11 T Dong et al., "Social Media and Internet Public Events", Telematics and Informatics, Vol. 34 No. 3 (2017), p. 726-739, https://doi.org/https://doi.org/ 10.1016/j.tele.2016.05.024.

12 M Hamilton et al., "Social Media and Value Creation: The Role of Interaction Satisfaction and Interaction Immersion”, Journal of Interactive Marketing, Vol. 36 (2016), p. 121-133, https://doi.org/https://doi.org/10.1016/ j.intmar.2016.07.001.

13 F. P Tajudeen et al., "Understanding the Impact of Social Media Usage among Organizations”, Information and Management, Vol. 55 No. 3 (2018), p. 308321, https://doi.org/https://doi.org/10.1016/j.im.2017.08.004.

14 W Creswell, J., Educational Research: Planning, Conducting Abd Evaluating Quantitative Dan Qualitative Research (4th Ed.), (Boston: Pearson Education, Inc, 2012).

15 Wahid Foundation, "Laporan Riset Potensi Radikalisme Di Kalangan Aktivis Rohani Islam Sekolah Sekolah Negeri”, 2016.

16 Nabila Fauziah Gardita, "Peran Pengurus Besar Nahdlatul Ulama (PBNU) Dalam Mencegah Radikalisme Agama Di Indonesia Pada Tahun 2018”, 2018.

17 Ali Mas'ud et al., "Program Penalaran Islam Indonesia Dan Gerakan KontraRadikalisme”, Jumal Pendidikan Agama Islam (Journal of Islamic Education Studies), Vol. 6 No. 2 (2019), p. 175-202, https://doi.org/10.15642/jpai.2018.6.2.175202.

18 Jakaria Umro, Loc.Cit.

19 Abd Rasyid Rahman, "Peran Agama Dalam Memperkuat Integrasi Nasional (Dalam Prespektif Sejarah)”, Lensa Budaya: Jurnal Ilmiah Ilmu-Ilmu Budaya, Vol. 12 No. 1 (2017), p. 101-109, https://doi.org/http://dx.doi.org/10.34050/ jlb.v12i1.3049.

20 Nabila Fauziah Gardita, Loc.Cit.

21 Musdah Mulia, "Bahaya Radikalisme Dan Kekerasan Ekstrimisme”, Al-wardah: Jurnal Kajian Perempuan, Gender dan Agama, Vol. 12 No. 2 (2018), p. 96-106,

22 Aminah Aminah, "Gerak Muslimah Di Antara Maraknya Feminisme Dan Isu Radikalisme: Analisis Pedagogi”, an-Nisa, Vol. 11 No. 2 (2019), p. 417-431, https://doi.org/10.30863/annisa.v11i2.338.

23 Nabila Fauziah Gardita, Loc.Cit.

24 Ali Mas'ud et al., Loc.Cit.

25 Jakaria Umro, Loc.Cit.

26 Ervi Siti Zahroh Zidni, "Kemitraan Keluarga Dalam Menangkal Radikalisme”, Jumal Online Studi Al-Qur'an, Vol. 14 No. 1 (2018), p. 32-43, https://doi.org/ 10.21009/jsq.014.1.03. 


\section{REFERENCES}

Alalwan, A. A. "Investigating the Impact of Social Media Advertising Features on Customer Purchase Intention”. International Journal of Information Management. Vol. 42 (2018), p. 65-77. https://doi.org/https://doi.org/10.1016/ j.ijinfomgt.2018.06.001.

Aminah, Aminah. "Gerak Muslimah Di Antara Maraknya Feminisme Dan Isu Radikalisme: Analisis Pedagogi”. An-Nisa. Vol. 11 no. 2 (2019), p. 417-431. https://doi.org/10.30863/annisa.v11i2.338.

Creswell, J., W. Educational Research: Planning, Conducting Abd Evaluating Quantitative Dan Qualitative Research (4th Ed.). Boston: Pearson Education, Inc, 2012.

Dong, T et al. "Social Media and Internet Public Events". Telematics and Informatics. Vol. 34 no. 3 (2017), p. 726-739. https://doi.org/https://doi.org/10.1016/ j.tele.2016.05.024.

Foundation, Wahid. "Laporan Riset Potensi Radikalisme Di Kalangan Aktivis Rohani Islam Sekolah Sekolah Negeri”., 2016.

Gall, J. P et al. Applying Eduactional Research: A Practical Guide. 5th. Ed. Boston: Pearson Education, Inc, 2005.

Gardita, Nabila Fauziah. "Peran Pengurus Besar Nahdlatul Ulama (PBNU) Dalam Mencegah Radikalisme Agama Di Indonesia Pada Tahun 2018”., 2018.

Hamilton, $\mathrm{M}$ et al. "Social Media and Value Creation: The Role of Interaction Satisfaction and Interaction Immersion". Journal of Interactive Marketing. Vol. 36 (2016), p. 121-133. https://doi.org/https://doi.org/10.1016/ j.intmar.2016.07.001.

Kaplan, Andreas M, and Michael Haenlein. "Users of the World, Unite/! The Challenges and Opportunities of Social Media”. Business Horizons. Vol. 53 (2010), p. 59-68. https://doi.org/10.1016/j.bushor.2009.09.003.

Khairuni, Nisa. "Dampak Positif dan Negatif Social Media Terhadap Pendidikan Akhlak Anak”. Jurnal Edukasi. Vol. 2 no. 1 (2016), p. 91-106.

Kuntarto, Kuntarto, and Rindha Widyaningsih. "Prosiding Seminar Nasional Dan Call for Papers". In Prosiding Seminar Nasional Dan Call for Papers, "Pengembangan Sumber Daya Perdesaan Dan Kearifan Lokal Berkelanjutan VIII"., 218-226. Purwokerto, 2018.

Mas'ud, Ali et al. "Program Penalaran Islam Indonesia Dan Gerakan KontraRadikalisme". Jumal Pendidikan Agama Islam (Journal of Islamic Education Studies). Vol. 6 no. 2 (2019), p. 175-202. https://doi.org/10.15642/jpai.2018.6.2.175202.

Mulia, Musdah. "Bahaya Radikalisme Dan Kekerasan Ekstrimisme”. Al-Wardah: Jurnal Kajian Perempuan, Gender Dan Agama. Vol. 12 no. 2 (2018), p. 96-106.

Nikzad-Terhune, $\mathrm{K}$ et al. "The Impact of the Internet and Social Media on Caregiving". Family Caregiving in the New Normal., 2015, 269-289 https:// doi.org/https://doi.org/10.1016/B978-0-12-417046-9.00015-5.

Rahman, Abd Rasyid. "Peran Agama Dalam Memperkuat Integrasi Nasional (Dalam Prespektif Sejarah)”. Lensa Budaya: Jumal Ilmiah Ilmu-Ilmu Budaya. Vol. 12 no. 1 (2017), p. 101-109. https://doi.org/http://dx.doi.org/10.34050/ 
jlb.v12i1.3049.

Rosowulan, Titis. "Gerakan Kesetaraan Gender antara Modetarisme Islam dan Radikalisme”. Wahana Islamika: Jurnal Studi Keislaman. Vol. 3 no. 1 (2017), p. $22-42$.

Sholikin, Ahmad. "Potret Sikap Radikalisme Menuju Pada Perilaku Terorisme Di Kabupaten Lamongan”. Journal of Governance. Vol. 3 no. 2 (2018), p. 184-202.

Siti Zahroh Zidni, Ervi. "Kemitraan Keluarga Dalam Menangkal Radikalisme”. Jurnal Online Studi Al-Qur'an. Vol. 14 no. 1 (2018), p. 32-43. https://doi.org/ 10.21009/jsq.014.1.03.

Sunarto, Andang. "Dampak Media Sosial Terhadap Paham Radikalisme”. Nuansa. Vol. 10 no. 2 (2017), p. 126-132.

Tajudeen, F. P et al. "Understanding the Impact of Social Media Usage among Organizations”. Information and Management. Vol. 55 no. 3 (2018), p. 308-321. https://doi.org/https://doi.org/10.1016/j.im.2017.08.004.

Umro, Jakaria. "Upaya Guru Pendidikan Agama Islam Dalam Mencegah Radikalisme Agama Di Sekolah”. Journal Of Islamic Education (JIE). Vol. 2 no. 1 (2017), p. 89-108. 